\title{
Porozumenie v spoločenskovednom výskume
}

\section{Peter Ondrejkovič}

\author{
Kontakt na autora \\ Univerzita Hradec Králové, \\ Pedagogická fakulta, \\ Rokitanského 62, \\ 50003 Hradec Králové \\ peter.ondrejkovic@uhk.cz
}

\section{Contact to author}

University of Hradec Králové, Faculty of Education, Rokitanského 62, 50003 Hradec Králové peter.ondrejkovic@uhk.cz

Copyright (C) 2016 by authors and publisherTBU in Zlín. This work is licensed under the Creative Commons Attribution International License (CC BY).

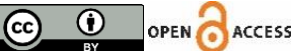

\begin{abstract}
Abstrakt: Témou príspevku je porozumenie ako odhal'ovanie významu alebo zmyslu sociálnych javov, udalostí, vztahov a procesov, situácií alebo i samotného postavenia výskumníka v istom sociálnom kontexte, ktoré sa stávajú klúčovými pojmami humanitných vied. Obsahuje aj malý exkurz do empirickej sondy, v ktorej sa pracovníci v humanitnej sfére pokúšajú vlastnými slovami napísat', čo si pod porozumením predstavujú, kedy sa nazdávajú, že skutočne porozumeli sociálnemu javu, vztáahu, procesu, prípadne i sebe. Príspevok v závere uvádza význam porozumenia, ktoré zdôrazňuje i zaradenie sociálneho rozmeru medzi všeobecné priority EÚ.
\end{abstract}

Klíčová slova: porozumenie, význam, teória rečových aktov, porozumenie $v$ hermeneutike, konštrukcionizme, etnometodológii a interpretativizme

\section{Understanding in the Social Research}

\begin{abstract}
The theme of this paper is understanding in the sense of revelation of meaning or sense of social phenomena, events, relationships and processes, situations and the position of a researcher in a certain social context, all of which are becoming key concepts in the humanities. It also includes a small empirical excursion, in which workers in the humanitarian sphere attempt to write in their own words what they mean by understanding, when they consider that they truly understand the social phenomenon, relationship, process, or even themselves. The conclusion indicates the importance of understanding, which is highlighted by adding the social aspect to general EU priorities.
\end{abstract}

Keywords: understanding, sense, theory of speech acts, understanding in hermeneutics, constructivism, ethnomethodology and interpretativism

\section{Stručný úvod do problematiky porozumenia}

V spoločenskovednom výskume, vrátane sociálnej pedagogiky, neraz predstavuje kategória porozumenia takmer axiologizujúcu samozrejmost', ktorú netreba d'alej vysvetl'ovat', ktorej všetci rozumejú, neraz skôr intuitívne ako racionálne. V škole sa celkom bežne stretávame pri vysvetl'ovaní učiva sotázkou vyučujúceho: „Rozumeli ste?“. Osobitnú kapitolu by predstavoval problém, ako porozumel študent textu, s ktorým sa stretáva $v$ priebehu štúdia. $K$ riešeniu podobných otázok má prispiet' nasledovný text, ktorý si kladie za ciel' súčasne upozornit' na nevyhnutnost' d'alšieho skúmania a komparácií jestvujúcich teórií. 
Porozumenie má v našom živote nemalý význam. Neraz určuje naše konanie, jeho prostredníctvom sa sami poznávame, budujeme svoje vztahy k sebe i svojmu okoliu, volíme cesty a spôsob života. Iste jestvujú veci, javy, procesy i vztahy, ktorým porozumiet' nie je l'ahké.

Porozumenie sa stáva klúčovým pojmom humanitných vied, osobitne interpretatívnej sociológie a sociálnej pedagogiky. $V$ nich nie je skutočnost' človeku jednoducho daná, ale je predmetom neustálej interpretácie aktérov sociálneho života. Teda toho, ako rozumejú tomu, čo robia iní, ako rozumejú výtvorom svojim aj ostatných, ako rozumejú jazyku a symbolom, všetkému, s čím prichádzajú do styku a ako k porozumeniu dospievajú. To si súčasné spoločenskovedné disciplíny uvedomujú, reflektujúc samé seba a preto sa stávajú súčasne aj reflexívnymi. „Alternatíva, komplementarita, pluralita a tolerancia predpokladajú porozumenie $v$ štandardnom a vo vysoko sofistikovanom zmysle“, uvádza Petrusek (1993, s. 145). K tomu patria nie iba "zdravý rozum“, ale aj prekonávanie náhodilosti, nekvalifikovanosti, naivnosti, ktoré môžu byt́ niekedy dokonca nebezpečné, pretože „....čím složitejší je moderní společnost... tím méně je srozumitelná pro lidi... nesrozumitelnost a nesamozřejmost našeho života... si uvědomíme až tehdy, když narazíme na problém..." (Petrusek, 2009, s. 15, 31)

Porozumenie pokladáme za obsahové pochopenie stavu veci, ktoré nespočíva iba v tom vziat́ niečo na vedomie, ale aj intelektuálne sa zmocnit' súvislostí, v ktorých stav veci spočíva. Porozumenie znamená podla Wilhelma Diltheya ${ }^{1}$ rozpoznanie $z$ daných vonkajších pozorovatel'ných znakov "vnútorné", (sociálno)psychické. Porozumenie sa často zamieňa za vysvetlenieím, s ktorým úzko súvisí ale nie je totožné. Žial', súčasný vývoj vo vede poznamenal predstavitel'ov sociálnych (humanitných) vied tak, že „...si už takmer nerozumejú a navzájom nekomunikujú“ (Sedová, 2011, s. 769). Podl'a tvrdení viacerých autorov je to dôsledok vítazstva tzv. prírodných vied v súperení dvoch kultúr. Prírodné vedy „zvítazili“ tým, že sa „... zaštítili svojou pragmatickou efektívnostou a neodškriepitel'ným praktickým, technickým a technologickým prínosom... pričom... v týchto pretekoch, v ktorých nešlo o nezištnú lásku k pravde, uspeli a získali náskok pred sociálnymi vedami“ (Sedová, 2011, s. 770). Sociálne vedy, ktorých jadro spočíva vo vedách o správaní, na rozdiel od prírodných vied však nemôžu existovat' bez kontextov poznávania konania, ktorého podstata spočíva v porozumení. Ako uvádza Fay (2002, s. 139 a nasl.), podl'a interpretativizmu jestvuje zásadný rozdiel medzi skúmaním človeka a spoločnosti a skúmaním prírody. Vedecké pojmy majú k sociálnym javom zásadne iný vztah, ako k prírodným javom. V sociálnych vedách pojmy vytvárajú skúmanú realitu, kým v prírodných vedách slúžia k popisu a vysvetleniu javov. Význam danej veci závisí od roly, ktorú má táto vec $v$ systéme, ktorého je súčastou. $V$ prípade sociálnych vied ide o systémy nesmierne komplexné a bohaté, $v$ ktorých zohrávaúlohu aj presvedčenie, l'udská túžba a zámery konkrétnych lúuí. Konanie, správanie, ktoré je úmyselné, teda intencionálne, je vyvolané istým druhom situácií alebo udalostí, ktoré si konajúci uvedomuje. Je najvlastnejším „premostením“ medzi človekom a jeho prostredím vprírode. Základom konania je porozumenie svojmu konaniu ikonaniu iných, čo je nevyhnutné pri pretváraní východísk (vstupných daností) na výstupné danosti (ciele). Iba v súvislosti s týmto druhom činnosti má zmysel hovorit o konaní.

Preto na rozdiel od vysvetlenia porozumenie ${ }^{2}$ možno charakterizovat' ako odhal'ovanie významu ${ }^{3}$ alebo zmyslu sociálnych javov, udalostí, vztahov a procesov, situácií alebo i samotného postavenia výskumníka v istom sociálnom kontexte.

1 Podrobnejšie pozri o tom Lessing (2001).

2 Neraz je vhodné použit termín chápanie vo význame porozumenia. V tomto význame hovorí o chápaní aj Lyotard (1999, s. 78). Podl'a Herbarta Blumera l'udia, veci ako i inštitúcie majú pre nás význam, ktorý je ústredným problémom symbolického interakcionizmu. A najvhodnejšou metódou pre riešenie toho problému je práve interpretácia. Blumer vychádza z troch premís: (a) Ĺudia konajú voči „veciam“ na základe významu, ktoré pre nich znamenajú. K „veciam“ patria aj luudia, situácie a inštitúcie. (b) Ich samotný význam je odvodený, alebo priamo spočíva v sociálnych interakciách, do ktorých vstupujeme s l'ud'mi. (c) Významy 
Vynára sa otázka, ako je vôbec možné pochopit to, ako druhí konajú? Nie je práve $v$ tejto oblasti podstata porozumenia konaniu? (Sedová 2011, s. 769-782). Simon Blackburn sa pýta, či si jeden druhému rozumieme. Jeho odpoved' znie áno. Toto áno čiastočne zmierňuje, ked' dodáva, že „,... rozumieme jeden druhému do vel'kej miery... pretože máme spoločný jazyk... slová majú význam, a preto ak vám niečo oznamujem, dokážete nahliadnut', čo tým myslím... a práve v tom spočíva porozumenie... Slová vo svojom prvotnom alebo bezprostrednom význame (podla Johna Locka) nezastupujú nič iného, ako idey v mysli toho, kto tieto slová užíva. Slová nám umožňujú nechat' druhých nahliadnut do súkromnej komnaty, ku ktorej máme inak prístup iba my sami“ (Blackburn, 2012, s. 76).

Viacerí autori zdôrazňujú odkrývanie (neraz skrytej) motivácie, ktoré má prispiet' k sprístupneniu subjektívnych aspektov konania (druhých). K porozumeniu patrí prípadne aj schopnost' tieto javy, udalosti a procesy $v$ sociálnom kontexte interpretovat', artikulovat' $v$ reči. Porozumenie môže znamenat' aj celostné vedenie, dosiahnuté bezprostredným prežívaním a chápaním (nielen rozumovým). Neraz hovoríme aj o vcítení, empatii, bezprostrednom uchopení podstaty príslušného sociálneho javu, najčastejšie na základe pozorovania, rozhovoru. $V$ takom prípade máme do činenia s umením (zručnostou) preniest' sa do života osoby, skupiny, alebo javu, ktorému má výskumník porozumiet'. Porozumenie bude teda závislé aj od príslušnej kultúry, sociálnej skupiny, vzdelania a intelektu výskumníka. Habermas $(1981$, s. 70) v tejto súvislosti uvádza, že porozumenie nemôže byt' normatívne pripisované, ale že ho dosahujeme komunikatívne.

Nesporný význam musíme pripísat' jazyku, Austinovej teórii rečových aktov ${ }^{4}$ (Austin, 2004), podla ktorej výpoved'ou neoznačujeme iba istý obsah alebo skutočnost', ale výpoved' ako rečový akt môže slúžit $k$ uskutočneniu istého alebo celkom iného konania. Teória rečových aktov teda postuluje komunikatívnu kompetenciu, ktorá obsahuje schopnost' aplikáciou výpovede konat' a otvára otázky na základy systému, princípy a pravidlá, ktorými disponujú ten kto hovorí a ten, kto je jeho poslucháčom. Austin pritom rozlišuje konštatačné výpovede (tvrdenia), ktoré môžu byt' pravdivé alebo nepravdivé a performatívne výpovede, ktoré sa môžu podarit', alebo aj nie, t.j. môžu a nemusia viest' k zmene konania, pričom otázka o ich pravdivosti je irelevantná.

Hans Georg Gadamer (1960) uvádza, že ak chceme niečo poznat', musíme podla hermeneutiky používat' aj iné postupy, akými sú tradičná metodológia a gnozeológia. Musíme vediet' aj načúvat', nechat' sa oslovovat' a tiež sa aj pýtat. Javy okolo nás musíme chápat' nie iba ako fakty, ale ako niečo, čo svedčí o tom, že aktéri, ktorí sa podiel'ali na vzniku príslušného javu, tento vlastne „zanechali“ ako jednu z možných odpovedí na množstvo otvorených otázok. Gadamer zdôrazňuje, že sa musíme naučit' vo vede a výskume pýtat' sa s nimi, nepovažovat' nič za hotovú odpoved' (definitívny jav), ale ako problém, s ktorým sa musíme zžit', ak máme odkryt' všetky jeho významy vo všetkých jeho vrstvách. Preto je podla Gadamera hermeneutika predovšetkým umením interpretácie. Pokladáme však za dôležité upozornit', že v prípade vcítenia (empatie ako podmienky nadväzovania sociálnych vztahov $)^{5}$ je vždy treba overovat', či sú správne hypotézy, príp. otázky, ktoré z problému vyplývajú.

vznikajú, používajú sa a menia v procese interpretácie, v ktorom sa s významami ludia dostávajú do styku (Blumer, 1969).

3 Podl'a Šefránka (2002) neexistuje jeden pravý a správny pojem významu. Možno skonštruovat' a používat' mnoho pojmov významu. Tieto konštrukcie treba ocenit' vtedy, ked'sa s ich pomocou dajú formulovat' a riešit zaujímavé problémy.

4 Austinova teória rečových aktov: Austin (2004) delí rečové akty na lokučné, ilokučné a prelokučné, na základe toho, či činnostou myslíme vyslovenie nejakej vety, t.j. akt vykonáme, ked' niečo povieme, alebo tým, že niečo povieme, konáme, alebo aktom myslíme zmenu myšlienok, pocitov a konania poslucháčov a hovoriacich. Existujú aj iné delenia, napr. na fonetické, fatické a retické atd'.

5 Dôležitou podmienkou rozvoja schopnosti empatie sú sociálne vztahy, v rámci ktorých jednotlivec posudzuje a vyhodnocuje signály druhého človeka - primárne vo vztahu k sebe (ako ho má ten druhý rád, nakol'ko si ho váži, čo ten druhý z jeho správania akceptuje a čo pokladá za nesprávne atd'.), sekundárne aj so záujmom práve o toho druhého človeka (ako sa cíti, čo prežíva, prečo sa tak správa atd'.). Vd'aka týmto 
Gadamer zdôrazňuje, že „porozumět znamená být ve vztahu zároveň s 'věcí samou', jež se projevuje skrz tradici a s nějakou tradicí, odkud ta 'věc' může ke mně mluvit." ${ }^{6}$

\section{K otázke zmyslu}

V procese porozumenia podla jedného z prúdov vo fenomenologickej sociológii a etnometodológii je dôležité nielen to, akým spôsobom sa snažíme porozumiet' svetu, v ktorom žijeme, ale najmä to, aby sme tomuto svetu dali sami zmysel (Garfinkel, 1967)7. V tomto zmysle chápanie súvisí i s konštrukcionizmom ${ }^{8}$, kedžze chápanie súvisí s konštrukciou znovuvytvorenia zmyslu poznávaného. Opisovanie a rozprávanie sa vždy uskutočňuje vo vnútri nejakého rámca, ktorý zabezpečuje pojmové prostriedky pre popis reality a pre jej prerozprávanie. Podla toho každé poznávanie a následne vedenie ako konštrukcia nevyhnutne vychádza z hladísk, ktoré sú definované sociálnymi, kultúrnymi, intelektuálnymi, politickými, morálnymi, príp. ekonomickými záujmami príslušnej konštrukcie vedenia. Každé vedenie je teda chápaním z určitej perspektívy (Ondrejkovič, 2004, s. 42). Stávanie sa zmysluplným prostredníctvom chápania (otázkou je či aj porozumenia) je súčasne inscendenciou (z lat. in-sciens, tiež in-scendo), vstupovaním chápajúceho človeka do seba samého, sebaprehlbovanie a do určitej miery i spiritualizácia a humanizácia.

Marleau-Ponty koncipuje dianie života ako ontologickú paradigmu. V tejto paradigme hladajúc zmysel je reč tela tohto sveta taká, ako akéhokolvek univerzálneho média, v ktorom sa až z rozpoznania (poznania) konštituuje ako poznané, ale ktoré musí poznanie znovu zniest' (spracovat'). Čo mi prinesie a umožní takto vidiet' (zmysel) je len viditel'ná sebareferencia, videnie seba, ktorá je prítomná nie ako priama evidencia, ale ako nepostrehnutel'ná, ktorá je prítomná nepriamo, ako tvarovo jednotiaci vztáah. Priamy dôkaz ale nie je ako niečo nepostrehnutel'né; je to nepriamo prítomné ako tvarovo (jednotiace). Telo ${ }^{9}$ bude teraz (podla toho) znamenat' stelesnenie nepostrehnutel'ného a zmysel tvoriace hranice vnímania (Danzer, 2003).

\section{Otvorené otázky}

Porozumenie je súčasne aj interpretačný postup, ktorým možno odkrývat špecifickost' predmetu neprírodovednej vedy, na rozdiel od „úspešnejšej" metódy prírodných vied (Balon, 2007). Porozumenie znamená predovšetkým porozumenie intenciám a motívom ludského (sociálneho) správania, ako súčasti porozumenia "veci“ a preto porozumenie nie je možné previest' do kauzálneho zákona alebo kauzálneho vysvetlenia.

signálom môžu sociálne vztahy pretrvávat' a vyvíjat’ sa. Spomínané signály majú predovšetkým neverbálnu podobu. Prvotným, vel'mi dôležitým vztahom, ktorý môže významne prispiet' (ale aj naopak - mat' rušivý vplyv) k rozvoju schopnosti empatie, je, pochopitel'ne, vzt́ah matka - diet́a, resp. rodičia - diet́a. V neskoršom veku postupne rastie vplyv sociálnych vztahov s d’alšími osobami (príbuznými, rovesníkmi, učitel'mi a pod.).

6 Kudrna (1964, s. 96).

7 Podl'a Garfinkela každý účastník interakčných aktov je vlastne praktický sociológ. Sociológia preto nie je ničím iným, než snahou pochopit' to, čo ludia robia, aby rozumeli svetu v ktorom žijú a konajú.

8 Na odlišenie konštruktivizmu $v$ umení, literatúre a architektúre a v spoločenských vedách sa prikláňame k požívaniu termínu konštrukcionizmu. Rozumieme pod týmto pojmom ludské vnímanie, ktoré je konštrukciou a jej interpretáciou. Ĺudský mozog rozumie len svojej vlastnej „reči“, jeho spojenie so svetom sa uskutočňuje prostredníctvom receptorov. Mozog pritom nereprodukuje skutočnost', sprostredkovanú receptormi, ale vykonáva istú redukciu. Výsledkom je naše vedenie ako výsledok konštrukcie, nie poznatok.

9 Človek, podla Marleau-Pontyho, ktorý dáva zmysel všetkému, nemá telo, ale je telom. Človek a jeho (l'udské) správanie je organizačným princípom nášho sveta. Nájst' seba v zmysluprázdne a navrhnút' sa v ňom znamená objavit' zmysel. Vedomie seba, tela a dejín obsahujú štruktúry, prostredníctvom ktorých realizujeme zmysel (Marleau-Ponty, 1974). 
Treba však upozornit' na snahy spochybnit' spoločenskovedný výskum z dôvodov prehnaného zdôrazňovania rozdielov podmienok, z ktorých vychádzajú tie hl'adiská, z ktorých vychádza naše vedenie. Ako príklad uvádza Fay (2002, s. 15 a nasl.), že by sa zdalo, že l'udí z určitej skupiny môžu poznat' (rozumej porozumiet' - pozn. autora) iba l'udia z rovnakej skupiny. Iba ženy môžu rozumiet' ženám, iba Afroameričania môžu poznat' Afroameričanov, iba Rómovia môžu porozumiet' Rómom. Táto problematika sa stáva zrejmá, ked' budeme inými slovami tvrdit', že aby sme niekoho poznali, musíme nimi byt' (Fay, 2002, s. 15). Iná je už otázka, či niekoho poznat' znamená aj mu rozumiet'.

Ked' pripustíme, že porozumenie nie je možné previest' do kauzálneho zákona alebo kauzálneho vysvetlenia, možno si pomôct' jednoducho jazykovou analýzou textu alebo jazykového prejavu, pričom skúmame význam slov a ich väzieb. Možno si pomôct' aj logickou analýzou, pri ktorej skúmame vnútorné skíbenie prejavu, vrátane zistovania logických vád, nejasností, medzier a skratiek, príp. logických skokov. Nezaobídeme sa ani bez výstavby prejavu ako celku, vrátane jeho členenia. $\mathrm{K}$ interpretácii patrí celkom prirodzene aj kontext, umiestnenie prejavu $\mathrm{v}$ jeho súvislostiach.

\section{$4 \quad$ Malý exkurz do empírie}

K odpovedi, ktorá sa nedá vyjadrit', nemožno podl'a Wittgensteina vyjadrit' ani otázku. „O čom nemožno hovorit', o tom treba mlčat"“ (Wittgenstein, 1984, s. 85). Ked' sa dá otázka vôbec položit', možno na ňu aj odpovedat'. Požiadali sme preto pracovníkov pôsobiacich v humanitnej sfére, aby sa pokúsili vlastnými slovami napísat', čo si pod porozumením predstavujú, kedy sa nazdávajú, že skutočne porozumeli sociálnemu javu, vzt́ahu, procesu, prípadne i sebe. Stručná obsahová analýza preukázala značné rozdiely v chápaní pojmu porozumenie. Takmer všetci (22 participanti) sa zhodli $v$ tom, že samotné porozumenie je proces s rôznou dĺžkou trvania. Náhle "osvietenie" s významom porozumenia sa vyskytuje zriedka, ale i vtedy je spravidla výsledkom dlhoročných skúseností a vzdelania. K výzve predstáv o porozumení odpovedali pedagógovia i sociológovia.

Významná predstavitel'ka staršej generácie hereckého umenia, činná i vo vede, výskume a pedagogickom procese, $v$ rozhovore uviedla, že:

„... stvárnenie roly herca je spravidla výrazom porozumenia. Vtedy už nie režisér a jeho príkazy, ale osobné porozumenie role v sociálnom kontexte ju skutočne dotvára".

Gavora a Šrajerová (2009) uvádzajú, že porozumenie textu je najdôležitejšia činnost' pri čítaní; čítat' bez porozumenia vlastne nemá zmysel. V školskom prostredí má porozumenie textu klúčovú úlohu - zefektívňuje učenie sa učiva. Učivo, ktoré žiak dobre pochopil, si lepšie integruje s predchádzajúcim učivom a dlhšie si udrží v pamäti.

„... Učitel' by mal preto vediet', do akej miery žiak rozumie čítanému textu. Mal by systematicky diagnostikovat' porozumenie textu, aby zistil silné i slabé stránky čítania žiaka a aby stanovil, akým problémom musí čelit'. Už dlhšie sa v diagnostike ujal názor, že chyby žiaka nie sú (len) nedostatkom, ale aj cenným diagnostickým údajom, ktorý musí učitel' poznat' a využívat" (Gavora \& Šrajerová, 2009).

Odlišný význam porozumeniu pripisuje učitel'ka na základnej škole:

"Sedela som nad tým "rozumiem", popísala som už kopec verzií, stále sa dostávam k tomu, že rozlišujem "rozumiem" niekomu a "rozumiem" niečomu. Ked" rozumiem niekomu, myslím, že je to o tom, že sa dokážem približit' jeho mysleniu, vcítit' sa, pochopit', ako sa dotyčný cíti, čo prežíva, čo potrebuje. Ak rozumiem niečomu, to znamená, že som pochopila, ako tá vec, proces... funguje, a dokážem tak potom túto vec použit na to, aby som si ul'ahčila nejakú prácu, ale aj to, že dokážem niečo d'alšie vytvorit' sama. Napr.: rozumiem tomu, ako mám pracovat' $\checkmark P C$ programe Imagine a ked'že viem, ako to funguje, tak dokážem vytvorit' v tomto programe interaktívne cvičenia pre deti."

Slovník i myslenie vedeckého pracovníka (SAV) neulahčujú charakteristiku porozumenia: 
„... otázka je podl'a mn̆a vel'mi dobre zodpovedaná vo Filozofických skúmaniach (L.W), kde porozumenie sa preukazuje $v$ schopnosti rozpoznat' pravidlo (súvislost') a pokračovat' správne $v$ postupnosti čisiel či $v$ hre, či správne používat' (nové/cudzie) slová. $V$ prípade argumentu či nejakého dôvodenia/textu sa porozumenie prejavuje $v$ schopnosti prerozprávat' či vyjadrit' argument svojimi slovami. $V$ interakcii tvárou $v$ tvár pri počúvaní rozprávania o nejakom zážitku, probléme, pocitoch (nemusí ist' len o interakciu, ktorá je súčastou výskumu) si overujem svoje porozumenie tak, že uvediem príklad niečoho podobného, čo som sama zažila, alebo poznám z literatúry a filmu a spýtam sa "rozprávača", či je to naozaj podobné, alebo nie. Ak nie, požiadam ho, aby mi uviedol nejaký d'alši príklad, ktorý je podobný. Takto postupujem aj vtedy, ked' mi niekto dáva vel'mi všeobecnú charakteristiku zážitku - napr. "učitel'ka ma šikanuje". Chcem poznat' čo najviac príkladov skúsenosti "šikanovania", aby som mohla porozumiet', ako dotyčný/á používa (rozumie) slovo šikanovanie".

Procesuálnu stránku porozumenia zdôrazňujú viacerí vedeckí pracovníci:

„... Porozumenie chápem ako stav, 'finálny produkt' istého procesu a deja, cez ktorý odkrývam problematiku istého javu, situácie, vzt'ahu a pod. Znamená to potom, že mám porozumenie, dospela som do štádia, že veci rozumiem.

Niečomu porozumiet pre mňa znamená porozumiet princípu fungovania daného javu, situácie (príčina - následok). Teda chápat' jeho základný mechanizmus: čím je tento jav spôsobený, ako - podl'a akých pravidiel, akým metódami, postupmi sa deje, ako prebieha a čo spôsobuje. Ak som niečomu porozumela, viem to opísat', zdôvodnit' prečo to vzniká a aké sú toho dôsledky".

Následne je tu aj príklad:

„Môj syn sa v istej situácii správa neprimerane danému kontextu ( $v$ škole, v rodine - vzhl'adom na jeho možnosti a vek). Porozumiet' pre mňa znamená predovšetkým zistit', prečo sa tak správa, čo dané reakcie vyvoláva. Porozumiet' pre mňa $v$ tejto situácii aj znamená prijat' interpretáciu dietata $k$ tomuto javu $-v$ príklade neprimeranému správaniu dietata. Porozumenie je potom porozumením prícinám, prejavom, dôsledkom tohto správania. Porozumiet' znamená pre mňa odkryt' príčinné vzt'ahy tohto javu z pohl'adu môjho, ale aj z pohl'adu dietata"a".

Participantka si d’alej kladie otázku, ako možno porozumiet' (vlastnému diet́atu):

„Otázkou je ako možno porozumiet' (ja som tá, ktorá chcem porozumiet') tomuto správaniu cez optiku iného - v tomto prípade dietáata. Porozumenie je tak vysoko individualizované poznanie, ktoré nemusí byt' v súlade s porozumením iného. Osobitne, resp. asi predovšetkým vo vztahoch a javoch týkajúcich sa l'udí. Myslím, že vo fyzike môže byt' porozumenie ovel'a transparentnejšie, čistejšie, menej subjektivne. Samozrejme v prípade, ak existuje nejaký jednotný pojmový aparát a všetci ho prijímajú a používajú".

S prehl'adným a dôkladným prístupom k porozumeniu sme sa stretli u d'alšieho participanta. I tu je príznačné, že je to nielen vedecký pracovník, ale i vysokoškolský pedagóg.

„Agnosco" (lat.) znamená rozpoznat', uvedomit' si. Iný význam slova porozumiet' v latinčine je comprehendo, teda uchopit niečo. $V$ angličtine zase pojem understand opisne hovorí o tom, že voči niekomu či niečomu je možné postavit' sa pod (za) niečo.

Americké školy prvej polovice 20. storočia (najmä etnometodológia, interpretavizmus) a vlastne všetky d'alšie teórie $v$ ich línii dodnes ako keby do dôsledkov popierali možnost' porozumenia si ludí navzájom. Etnometodológia z hl'adiska funkcionality priamo hovorí o tom, že porozumenie si slúži len na pocit vzájomného porozumenia a nie na reálne porozumenie si. Každý jeden totižto máme rozličné životné skúsenosti a v kombinácii s našou psychikou je nájst' zhodu na matematickej úrovni znamienka „=" (áno rozumiem čo hovoriš) možné len v pravdepodobnosti 
na úrovni permutácií bližiacich sa $k$ nekonečnu. Dá sa však vo všeobecnosti prijat' tvrdenie, že slovné vyjadrenie "rozumiem ti" smerujúce ku partnerovi má aj emocionálny a interakčný charakter a funkciu.

Ako chápat́ tento pojem v kultúrnych štúdiách?

Rozumiet niečomu v súčasnej teórii a chápaní kultúrnych štúdií (culture studies) a teórie kultúry sa dá vysvetlit' ako súladnost' medzi mojim vlastným videním reality a tým, ako si myslím, že je realita konštruovaná. Súhlasit' s niečím na základe porozumenia predpokladá teda, že moja predstava (moje videnie sveta) je rovnaké s tým ako $v$ danom momente vnímam to, čo sa deje pred mojimi očami.

Po tretie, a tu je najväčší problém, je otázkou, či je vôbec možné položit' znamienko "=" do vzt'ahu porozumenia medzi dvoma l'ud'mi. Ked' budeme chciet' ist' do najjemnejších porozumení rôznych vecí, tak bude nepravdivé tvrdenie, že l'udia si môžu porozumiet' a následne vyjadrit' súhlasný postoj. Na úrovni výrazne generalizovaných pojmov (chod', urob, počkaj), možno pravdepodobne často podfarbených normativitou, je to porozumenie medzi dvoma lud'mi výrazné a zároveň je závislé na dlǐ̌ke vyjednávania individuálnych porozumení. Tu by sa dal asi problém roztat'.

Je rozdiel porozumenia v kognitívnej a emocionálnej oblasti?

Pokial' hovoríme o probléme porozumenia si ludí v tzv. kognitívnej oblasti je porozumenie si medzi lud'mi výrazné a dokážu si porozumiet', pretože sú si vzájomne blízky na rôznych úrovniach (toho, že sú l'udia, predstavitelia jednej kultúry, jednej skupiny, jedného záujmového združenia) a to práve kvôli tomu, že použivajú rovnaký jazyk a zdiel'ajú rovnaké vysvetlenia vecí (napr. na pojme "kultúra" sa skôr zhodneme ako sociológovia než ako sociológovia a umelci - $v$ druhom prípade je potrebný dlhší vyjednávací čas na porozumenie si). $V$ konečnom dôsledku si ale myslím, že si môžeme porozumiet' - pozriet' sa z pohl'adu toho druhého, či rozpoznat', uvedomit'si jeho "slová".

$\checkmark$ emocionálnej oblasti je hl'adanie porozumenia silne podfarbené emocionálnym prežívaním. $\checkmark$ tejto oblasti sa omnoho viac uplatňuje empatia a z oboch interakčných strán sa ani neočakáva, že by si obe strany porozumeli do úplných detailov."

Z pohl'adu pedagóga a akademického funkcionára je často vnímaný pohl'ad na porozumenie ako istý nadhl'ad:

- $\quad$ snaha o pochopenie druhého človeka, alebo situácie, alebo nejakej veci,

- $\quad$ poznanie zázemia, ktoré sa so situáciou, vecou, človekom a podobne spájajú,

- $\quad$ poznanie informácií, ktoré s problémom, človekom, situáciou súvisia,

- $\quad$ vnímanie kontextu, v ktorom je informácia podávaná za účelom porozumenia,

- merané i vlastným postojom, resp. vztahahom k veci, človeku, situácií, ktorá je podávaná,

- konfrontáciou medzi vlastným presvedčením a zhodnotením stavu situácie, vktorej k porozumeniu má dochádzat'.

I medzi sociológmi sme sa stretli s pochybnostami o možnostiach porozumenia, dalo by sa povedat', že v zmysle Simon Blackburnovej otázky, či si jeden druhému rozumieme (Blackburn, 2012, s. 76).

Ja si osobne myslím, že tomu druhému nemôžeme nikdy porozumiet' dokonale. Môžeme sa o to pokúsit', byt' empatickí, ale nepreživame jeho situáciu, nemáme jeho životné skúsenosti (či pozitívne alebo negatívne). Porozumenie môže byt' intenzívnejšie, ak máme spoločné zážitky, skúsenosti a pod. Viem porozumiet' svojmu introvertnému a citlivému synovi, pretože sama som bola introvertným dietatóm (a stále si pamätám tie pocity). Môj muž má problém porozumiet' takému dietatúu, pretože celý život bol extrovert, pochádzal zo šiestich detí, kde si svoje miesto 
musel vydobyt. Myslím si ale, že je podstatné snažit' sa porozumiet', aby sme s tými druhými dokázali koexistovat'.

Medzi kvalifikované odpovede na otázku o porozumení možno zaradit' aj nasledovnú odpoved', skôr už esej na základe skúseností a dôkladnej úvahy participantky:

Vo vel'mi všeobecnej rovine môžeme pod porozumením mysliet' pochopenie podstaty, zmyslu, kauzality alebo významu niečoho - veci, javu a pod. $V$ tomto zmysle sa nám natíska pre porozumenie synonymum pochopenie. Iste však by sme tieto pojmy použili $v$ rozdielnych situáciách rozdielne, jednak podl'a osobnej jazykovej kultúry alebo podl'a objektu, ktorému treba porozumiet', pochopit' ho.

Porozumenie vníma participantka $v$ dvoch základných rovinách. $\mathrm{V}$ rovine porozumiet konkrétnym veciam, javom alebo procesom (napr. prírodovedná oblast') a $v$ rovine medziludských vztahov (sociálno-spoločenská oblast').

Prvá z uvedených rovín je založená v podstate na čisto zmyslovo-rozumovej, poznávacej báze a súvisí so schopnostou pochopit', osvojit' si konkrétny objekt porozumenia (vec, jav, proces), ktorému treba porozumiet'. Vychádza z úrovne poznatkov, schopností ich kombinovat' a vidiet' súvislosti (IQ).

Porozumenie v druhej, sociálno-spoločenskej oblasti je založené na osobnej vnútornej motivácii, záujme a empatii. Vychádza z predchádzajúcich skúseností, poznatkov a schopnosti vcítit' sa do konkrétnej situácie, vzt'ahov, druhého človeka alebo aj skupiny l'udí (EQ).

Vychádzajúc z uvedeného pokusu o konštrukt možného vysvetlenia porozumenia vidíme niektoré spoločné prvky, ktoré by sme mohli použit' v d'alšom pokuse, tentokrát o „všeobecnú definíciu porozumenia":

Porozumenie je výsledkom vedomej, vnútorne motivovanej snahy o pochopenie vecí, javov, procesov, alebo vzt'ahov za účelom ich poznania s cielom jeho d'alšieho využitia v činnosti človeka alebo jeho pôsobenia na okolie $v$ rámci komunikácie a medziludských vzt'ahov. $V$ spoločenskej oblasti porozumenie úzko súvisí so zaujímaním postojov $k$ spoločenským javom, iným l'ud'om a kvalitou vzt'ahov s nimi.

$\checkmark$ sociálno-spoločenskej rovine môžeme teda skrátene vol'ne povedat', že porozumenie je výsledkom vnútorne motivovanej snahy o pochopenie druhého človeka. Druhému človeku sme pravdepodobne porozumeli vtedy, ked' pochopime dôvody, resp. príciny jeho správania sa, prejavu a konania voči našej osobe alebo voči iným l'ud'om. Vždy však ide len o možnost', ktorá je determinovaná mierou nášho poznania druhej osoby v pokial' možno najširších súvislostiach, tiež ide o našu schopnost' empatie, intuície a tiež podmienené mierou motivácie porozumenia.

Preto úplne porozumiet' druhému človeku je nesmierne t'ažké, ak vôbec možné. Porozumenie $v$ medziludských vzt'ahoch je potrebné a snád'jedine aj možné ako niečo pozitívne, dobroprajné, čo nám umožňuje obohatit' náš vzt'ah $k$ inému človeku, pochopit' ho alebo aj nás samotných $v$ určitej situácii. Premisou tu však musí byt dobrý úmysel, pozitívna snaha, motivácia alebo aj láska.

Porozumenie bezprostredne súvisí, ba i podmieňuje súcit:

$\checkmark$ Budhovom učení je napr. premisou vzt'ahu $k$ iným bytostiam (l'ud'om, všetkým živým tvorom) schopnost' súcitu, ktorý je v tejto súvislosti možné vnímat' ako vyššiu úroveň empatie. Vd'aka súcitu Budha pochopil nielen zmysel a kolobeh života vo večnosti, ale aj sám seba ako jeho súčast'. Nazeranie na porozumenie z takejto alebo podobnej duchovnej roviny pravdaže otvára d'alšiu inú kvalitu priestorov pre vnímanie porozumenia, pretože tu už opúšt'ame l'udské hl'adiská a ocitáme sa v priestore, ktorý nás presahuje. 
Preexponovaný súcit bez schopnosti aj určitej miery kritického pohl'adu sa však môže stat' $v$ konečnom dôsledku zraňujúcim sklamaním. Preto porozumenie vychádzajúce z dobrej snahy a úmyslu nemôže byt' nikdy len jednostranným, ale aj akoby ponukou, darom druhej strane, ktorá by s ním mala rovnako pozitívne naložit' v rámci vzájomného vztáahu. Ak sa tak nestane, bud' sme sa teda napriek obojstrannej snahe vzájomne neporozumeli, resp. neboli sme toho schopní, alebo o to porozumenie druhá strana nemá záujem, nemá pre ňu význam. Tu myslíme prirodzene na vztahy dospelých l'udí, pretože vztáah $k$ detom je $v$ zretel'ne inej rovine. Tam východisko lásky, súcit a obetavost' ako východiská porozumenia sú nanajvýš potrebné a veríme, že diet'a vždy vníma takýto prístup, vzt'ah ako útočisko istoty a bezpečia zvlášt' $v$ zložitejších životných situáciách (biblický príklad návratu strateného syna, kde otvorená náruč nič sa nepýtajúceho otca objíma, chráni a odpúśtáa súčasne).

So zdôrazňovaním snahy (o porozumenie, stotožňované schápaním) sme sa stretli častejšie. Najvýraznejšie bola prezentovaná takáto snaha o stotožnenie u participantky so sociologickým vzdelaním:

Porozumenie je výsledkom snahy o pochopenie druhého človeka takého, aký skutočne je, rovnako jeho skutkov a postojov, pričom východiskom tejto snahy musí byt' pozitívna motivácia, dobroprajné myslenie, empatia alebo aj nezištná láska. Takéto porozumenie je však potrebné aj dat' zretel'ne najavo ako prejav ruky podanej s dobrým úmyslom pomôct', správne sa chápat' navzájom a tak sa spoločne usilovat' o kvalitný vztah. Akokolvek to znie ideálne, ba až romanticky, inej cesty niet, zvlášt' $v$ dnešnom svete relativizácie skutočných hodnôt a všetkého, čo vytvorilo a predstavuje dnešnú európsku civilizáciu.

Uvedené konštatovanie snahy o pochopenie druhého človeka takého, aký skutočne je, by sme mohli považovat' i ako záver malého empirického exkurzu do názorov na porozumenie, ktoré by si zaslúžilo osobitný výskum.

\section{Záver}

Porozumenie má v našom živote nemalý význam. Neraz určuje naše konanie, jeho prostredníctvom sa sami poznávame, budujeme svoje vztahy $\mathrm{k}$ sebe i svojmu okoliu, volíme cesty a spôsob života. Význam porozumenia zdôraznilo i zaradenie sociálneho rozmeru medzi všeobecné priority EÚ (EUR-lex, 2016). ${ }^{10}$

Ciel'om spoločenskovedných disciplín by sa malo stat' prispiet' k objasňovaniu zdanlivo známych a všeobecne používaných pojmov, medzi ktoré patrí aj porozumenie. Jeho osobitný význam nadobúda riešenie v sociológii, sociálnej pedagogike a sociálnej filozofii.

\section{Literatúra}

Austin, J. L. (2004). Ako niečo robit' slovami. Bratislava: Kaligram.

Balon, J. (2007). Sociologická teorie. Přiběh krize a fragmentace - projekt obnovy a rekonstrukce. Praha: SLON.

Blackburn, S. (2012). Velké otázky filosofie. Praha: Euromedia Group, Knižní klub.

Blumer, H. (1969). Symbolic interactionism; Perspective and method. Englewood Cliffs, NJ: PrenticeHall .

10 Uznesenie Rady a zástupcov vlád členských štátov zo zasadnutia Rady z 27. júna 2002 ustanovuje najmä otvorenú metódu koordinácie, ktorá sa vztahuje na priority, ktorými sú participácia, informovanost', dobrovol'nícke aktivity mladých l'udí a lepšie porozumenie mládeži. 
Danzer, G. (2003). Marleau-Ponty: Ein Philosoph auf der Suche nach Sinn. Berlin: Kulturverlag Kadmos.

EUR-Lex. (2016, Apríl 1). Přistup k próvu Evropské unie. Dostupné z http://eur-lex.europa.eu/

Fay, B. (2002). Současná filosofie sociálních věd. Praha: Slon.

Gadamer., H. G. (1960). Wahrheit und Methode. Grundzüge einer philosophischen Hermeneutik. Tübingen: Mohr.

Garfinkel, H. (1967). Studies in Ethnomethodologie. Pretince Hall: Engelwood Cliffs.

Gavora, P., \& Šrajerová, H. (2009). Porozumenie textu zistované cloze-testom vo vzt́ahu k niektorým charakteristikám žiakov. Slovo o slove, 15, 199-207.

Habermas, J. (1981) Theorie des Kommunikativen Handelns. Band I., Band II. Handlungsrationalität und gesellschaftliche Rationalisierung. Frankfurt am Main: Suhrkamp.

Kudrna, J. (1964). Studie k Hegelovu pojetí historie. Praha: Nakladatelství ČSAV.

Lessing, H-U. (2001). Wilhelm Diltheys 'Einleitung in die Geisteswissenschaften'. Darmstadt: Wissenschaftliche Buchgesellschaft.

Lyotard, J. F. (1999). Fenomenológia. Bratislava: SOFA.

Marleau-Ponty, M. (1974). Phänomenologie der Wahrnehmung. Berlin: De Gruyter.

Ondrejkovič, P. (2004). Socializácia v sociológii výchovy. Bratislava: VEDA.

Petrusek, M. (1993). Teorie a metoda v moderní sociologii. Praha: Karolinum.

Petrusek, M. (2009). Základy sociologie. Praha: Akademie veřejné správy.

Sedová, T. (2011). K niektorým aspektom interpretativizmu v sociálnom poznaní. Filozofia, (66)8, 769-781.

Wittgenstein, L. (1984). Tractatus logico-philosophicus. Frankfurt am Main: Suhrkamp.

Wittgenstein, L. (1993). Filosofická skoumání. Paha: Filosofický ústav AV ČR. 